\title{
(5)
}

AL-DZIKRA

Jurnal Studi Ilmu Al-Qur'an Dan Al-Hadits

http://ejournal.radenintan.ac.id/index.php/al-dzikra

Volume 11, No. 2, Desember Tahun 2017, Halaman 155 - 186

DOI://dx.doi.org/10.24042/al-dzikra.v11i2.4395

\section{INTERPRETASI AYAT-AYAT PSIKOLOGI DALAM SURAT YUSUF}

\begin{tabular}{c}
\hline Alim Sofiyan \\
UIN Raden Intan Lampung \\
alim.sofiyan@gmail.com \\
\hline
\end{tabular}

\section{Abstrak}

Artikel ini meneliti tentang ayat-ayat yang ada hubungannya dengan psikologis. Penelitian ini fokus dalam pembahasan terhadap emosi primer dalam surat Yusuf. Adapun ayat-ayat yang berkaitan dengan psikologis sangat banyak sekali, akan tetapi peneliti memfokuskan dalam kajian psikologis yang berkaitan dengan emosional manusia, dimana banyak ditemukan ayat-ayat yang bersentuhan langsung dengan emosi dalam surat Yusuf. Untuk memudahkan dalam penelitian ini, maka peneliti merumuskan pokok permasalahan yakni, bagaimana cara yang diajarkan Allah swt. dalam mengendalikan emosi dalam surat Yūsuf serta apa saja hikmahnya dalam surat Yūsuf. Penelitian ini termasuk dalam penelitian pustaka (library research) dengan menfokuskan pada interpretasi ayat yang berkaitan dengan psikologis, sehingga peneliti menggunakan metode content analysis dan interpretasi. Sehingga ditemukan bahwa cara mengendalikan emosi yang ada dalam Surat Yūsuf adalah dzikrullah, Al-'Afw, dan Sabar, yang harus selalu kita pegang sebagai kunci kesuksesan dan keberhasilan serta kemenangan dalam menjalani setiap kehidupan. 
Kata Kunci: Emosi, Al-Qur'an, Surat Yūsuf

\section{A. Pendahuluan}

Al-Qur'an merupakan kitab induk yang memberi petunjuk kepada kebenaran, sehingga permasalahan apapun telah ada penyelesaiannya di dalam al-Qur'an. Dalam hal ini Hasbi AshShidiqy mengatakan, bahwa al-Qur'an merupakan pengumpul segala makna dan hakikat, pengumpul hikmah dan hukum, sehingga dapat dikatakan bahwa al-Qur'an itu Kalamullah yang mengumpulkan segala ilmu ${ }^{1}$. Allah swt. berfirman dalam QS. anNahl: 89:

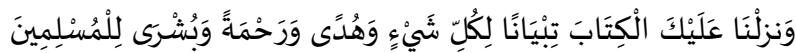

"Dan kami turunkan kepadamu al-Kitab (al-Quran) untuk menjelaskan segala sesuatu, sebagai petunjuk, serta rahmat dan kabar gembira bagi orang yang berserah diri".

Ibnu Jarir Attabari menafsirkan ayat di atas bahwa alQur'an adalah kitab yang diturunkan kepada Nabi Muhammad saw., penjelas terhadap semua yang dibutuhkan manusia, beliau juga mengutip riwayat dari Ibnu Mas'ud yang mengatakan bahwa al-Qur'an memuat segala ilmu dan segala sesuatu.

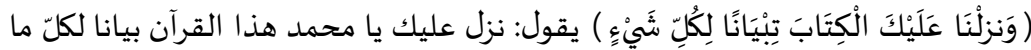

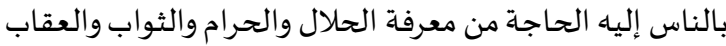

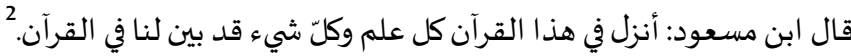

Secara garis besar asas epistimologi paradigma al-Qur'an dibagi menjadi tiga macam, yang pertama yaitu kauniayah (ilmuilmu alam, nomothetic), kedua qouliyah (ilmu-ilmu Qur'an theological) yang ketiga adalah ilmu nafsiyah. 'ilmu kauniyah berkenaan dengan hukum alam, 'ilmu kauliyah berkenaan dengan hukum Tuhan, dan 'Imu nafsiyah berkenaan dengan makna, nilai dan kesadaran. Ilmu nafsiyah inilah yang disebut sebagai humaniora (ilmu-ilmu kemanusiaan, hermeunetical ). Dan di

\footnotetext{
${ }^{1}$ Hasbi Ash-Shidiqy, Ilmu Al-Qur'an Dan Tafsir, (Semarang: Pustaka Rizki Putra, 2009), hlm. 6-7

${ }^{2}$ Muhamad Bin Jarir Bin Yazid Bin Katsir Bin Kholib Al-Amli, Abu Ja'far At-Thabari, Jami'ul Bayan Fi Ta'wil Qur'an, dari, Al-Maktabah AlSyâmilah. Tafsir Surat An-Nahl Ayat: 89, (Muassasah Al-Risalah, 2000), Jilid. 17, hlm. 278-279
} 
dalam bahasa Arab ilmu nafsiyah diartikan sebagai ilmu psikologi. ${ }^{3}$ Allah swt. berfirman dalam surat Fushshilat ayat: 53

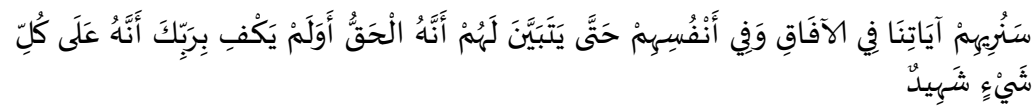

"Kami akan memperlihatkan kepada mereka tanda-tanda (kekuasaan) kami di segenap penjuru dan pada diri mereka sendiri, hingga jelas bagi mereka bahwa al-Quran itu adalah benar. Tiadakah cukup bahwa sesungguhnya Tuhanmu menjadi saksi atas segala sesuatu".

Kajian ilmu psikologi secara umum mempelajari gejalagejala kejiwaan manusia yang berkaitan dengan pikiran (kognisi), kehendak (conasi) dan perasaan (emotion). ${ }^{4}$

Daniel Goleman, menyebutkan bahwa ada ratusan emosi, bersama dengan campuran, variasi, mutasi, dan nuansanya. Goleman sendiri mengemukakan ada delapan emosi yaitu, amarah, kesedihan, rasa takut, kenikmatan, cinta, terkejut, jengkel, malu, kemudian dari emosi-emosi itu dikategorikan lagi kedalam emosi inti atau emosi dasar, yaitu takut, marah, sedih, dan senang. ${ }^{5}$

Ungkapan al-Qur'an tentang emosi manusia digambarkan langsung bersama peristiwa yang sedang terjadi, serta terdapat kesan pada ayat-ayat tersebut adanya perbedaan yang tajam antara emosi positif dan negatif. ${ }^{6}$ Misalnya seperti firman Allah swt. dalam surat ar-Rūm ayat: 36

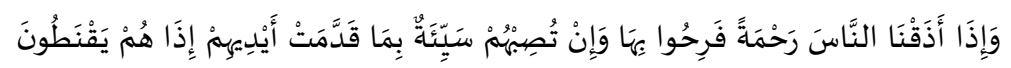

"Dan apabila kami berikan sesuatu rahmat kepada manusia, niscaya mereka gembira dengan rahmat itu. tapi apabila mereka ditimpa suatu musibah (bahaya) disebabkan kesalahan yang telah dikerjakan oleh tangan mereka sendiri, seketika itu mereka berputus asa".

${ }^{3}$ Kuntowijoyo, Islam Sebagai Ilmu, Epistemologi, Metodologi, dan Etika, (Yogyakarta: Tiara Wacana, 2006), Cet. 1, hlm. 25

Cet. 15 , hlm. 7

4 Jalaludin, Psikologi Agama, (Jakarta: Raja Grafindo Persada, 2011),

5 Daniel Goleman, Kecerdasan Emosional, Terjemah, Hariono S. Imam, (Jakarta: Gramedia Pustaka Utama, 1997), hlm. 411

${ }^{6}$ M. Darwis Hude, Emosi Penjelajahan Religio-Psikologis Tentang Emosi Manusia Di dalam Al-Qur'an, (Jakarta: Erlangga, 2006), hlm. 19 
Dalam ayat di atas dijelaskan bahwa perilaku kedua yang dapat mengantarkan manusia kepada kesyirikan adalah bila mereka diberi rahmat sedikit saja oleh Allah swt., mereka lupa daratan. Akan tetapi, bila ditimpa kemalangan sedikit saja, mereka putus asa lalu ingkar. Oleh karena itu, manusia tidak boleh cepat terlena bila memperoleh nikmat dan tidak boleh cepat putus asa bila mendapat kesusahan.

Emosi serta ekspresinya telah dimiliki manusia sejak dari awal kemudian diwariskan secara genetis dan terus berkembang akibat interaksi-interaksi yang dialami dalam hidupannya. ${ }^{8}$ Setiap individu ataupun masyarakat memiliki aturan, kapan dan bagaimana seharusnya emosi itu ditampilkan dan kapan saat emosi itu tidak harus ditampilkan, ini adalah merupakan hal penting dalam kehidupan manusia, khususnya untuk mereduksi ketegangan yang timbul akibat emosi yang memuncak. ${ }^{9}$ karena pengaturan atau pengendalian emosi (emotional regulation) sebenarnya telah dipelajari mulai dari bayi, ketika berinteraksi dengan ibunya, ibu menjadi model bagi bayi dalam mempelajari emosi, bayi meniru tanggapan emosional ibu terhadap berbagai situasi. $^{10}$

Daniel Goleman melalui bukunya yang terkenal Emotional Intelegence, (Kecerdasan Emosional) mencoba memberi tekanan pada aspek kecerdasan interpersonal atau antar pribadi, kecerdasan emosional dapat dirumuskan sebagai kemampuan meyelaraskan antar emosi dan nalar berupa keterampilan mengenali emosi dan mengelolanya, keterampilan memotivasi diri, kemampuan empati dan keterampilan memelihara hubungan sosial. $^{11}$

Teori Daniel Goleman tersebut selaras dengan penelitian James Gross mengenai Emotion Relgulatioon (Regulasi Emosi),

7 Departemen Agama RI, Al-Qur'an Dan Tafsir, (Jakarta: Lentera Abadi, 2010), hlm. 504

${ }^{8}$ Aliah B. Purwakania Hasan, Psikologi Perkembangan Islam, (Jakarta: Raja Grafindo Persada, 2008), hlm. 161

${ }^{9}$ M. Darwis Hude, Emosi Penjelajahan Religio-Psikologis, hlm. 256

${ }^{10}$ Aliah B. Purwakania Hasan, Psikologi Perkembangan Islam, hlm. 173

11 Sebagaimana Yang Dikuatip Mohamad Ali, Dalam Bukunya Pendidikan Untuk Pembangunan Nasional, (Jakarta: Grasindo, 2009), hlm. 140 
James Gross mengatakan emosi dapat menuntun kita ke arah yang salah, saat emosi kita terlihat tidak sesuai dengan situasi tertentu, kita sering mencoba mengatur respon emosi kita agar lebih bermanfaat untuk mencapai tujuan kita. Ia mendefinisikan regulasi emosi sebagai proses dengan mana kita mempengaruhi, mana emosi yang kita miliki, kapan kita memilikinya, dan bagaimana kita mengalami dan mengekspresikannya. ${ }^{12}$

Martin Wijokongko dalam bukunya Keajaiban Dan Kekuatan Emosi, beliau mengatakan bahwa Tuhan memberikan kita emosi untuk tujuan yang mulia yaitu agar manusia hidup bahagia, manusia yang mampu mengendalikan emosinya secara baik akan dapat meraih yang terbaik, karena pada dasarnya emosi adalah kekuatan yang luar biasa kalau dilakukan untuk tujuan yang positif dan membangun. ${ }^{13}$

Berbagai peristiwa dan pengalaman yang terkait dengan emosi yang diungkapkan al-Qur'an, baik secara eksplisit maupun implisit merupakan kisah masa lampau yang patut dijadikan pelajaran untuk kehidupan masa kini ataupun masa yang akan datang, karena al-Qur'an merupakan sumber kebenaran yang memiliki otoritas dalam keyakinan keagamaan. Dalam al-Qur'an sendiri kita dapat melihat kisah Nabi Yūsuf yang merupakan kisah terbaik sebagai pelajaran dalam kehidupan. Firman Allah swt. dalam surat Yūsuf ayat: 3

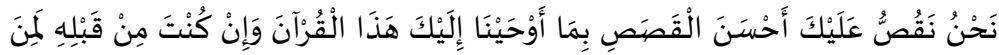

$$
\begin{aligned}
& \text { الْغَافِلِينَ نَحْنَ }
\end{aligned}
$$

"Kami menceritakan kepadamu kisah yang paling baik dengan mewahyukan al-Qur'an ini kepadamu, dan sesungguhnya kamu sebelum itu termasuk orang-orang yang tidak mengetahui".

Surat Yūsuf terdiri atas 111 ayat, termasuk golongan suratsurat Makkiyyah karena diturunkan di Makkah sebelum hijrah. Surat Yūsuf ini memuat konsep-konsep psikologi yang humanis,

12 Sebagaimana Yang Dikutip Charles C. Mans, Dalam Bukunya Emotional Dicipline, 5 Langkah Menata Emosi Untuk Merasa Lebih Baik Setiap Hari, Trj, Aloysius Rudi Purwanta, (Jakarta: Gramedia Pustaka, 2007), Cet. 2, hlm. 11

13 Martin Wijokongko, Keajaiban Dan Kekuatan Emosi, (Yokyakarta: Kanisiun, 2011), cet. 14, hlm. 16 
bahkan berbagai kaidah psikologi yang ditetapkan para ilmuwan Barat melalui penelitian panjang tidak dapat menandingi kaidah psikologi dalam surat ini. Kita dapat menemukan paparan mengenai berbagai konsep psikologi, seperti halnya tentang perasaan (emosi), motifasi, naluri, prinsip dan batasan. Selain itu juga mendapat paparan tentang berbagai fenomena kejiwaan, seperti cinta dan benci, tergila-gila dan tipu daya, rindu, dan kehilangan, penantian dan harapan, keputusasaan, keteguhan tekad, ketergesah-gesahan, kesedihan, kesunyian, penyesalan, permintaan ampun dan lain-lain. ${ }^{14}$

Salah satunya adalah seperti kecemburuan emosional saudara-saudara Yūsuf kepada Yūsuf, karena Ya'qūb lebih mencintai Yūsuf dan Buyamin dibandingkan dengan saudarasaudara Yūsuf yang lainya. Sehingga kebencian saudara-saudara Yūsuf, mengakibatkan dibuangnya Yūsuf ke dalam sebuah sumur. Perbuatan saudara-saudara Yūsuf tersebut mencerminkan kedangkalan dalam mengendalikan emosi, sehingga mengakibatkan kerugian pada diri sendiri dan juga orang lain. Karena sesungguhnya setiap individu ataupun masyarakat memiliki aturan, kapan dan bagaimana seharusnya emosi itu ditampilkan dan kapan saat emosi itu tidak harus ditampilkan, untuk mereduksi ketegangan yang timbul akibat emosi yang memuncak. ${ }^{15}$

Kalau kita perhatikan secara umum reaksi seseorang manakala tidak mampu mengendalikan ledakan-ledakan emosional ketika menghadapi masalah atau tekanan, seperti munculnya ekspresi murung, berperilaku kasar, tidak mau kompromi, dan sibuk melampiaskan amarahnya. Sementara ledakan emosi yang ditahan mengahasilkan gelisah, resah dan disertai perilaku paronoid, seperti menggigit kuku, menghela nafas, tertawa kecil dan sebagainya. ${ }^{16}$

${ }^{14}$ Fuad Al-Aris, Tafsir Psikologi Latha'if Al-Tafsir Min Surah Yūsuf, trj, Fauzi Bahrezi, dengan Judul, Pelajaran Hidup Surah Yūsuf, (Jakarta: Zaman, 2013), hlm. 10

${ }^{15}$ M. Darwis Hude, Emosi Penjelajahan Religio-Psikologis, hlm. 256

${ }^{16}$ Hendra Surya, Jadilah Pribadi Yang Unggul, (Jakarta: Gramedia, 2010), hlm. 41 
Ketidakmampuan mengendalikan emosi ini akan mempengaruhi pembentukan konsep diri (suara hati) yang tidak menguntungkan sehingga memperlihatkan ciri khas kepribadian yang tidak matang pada seseorang melalui perilakunya. ${ }^{17}$ Maka dalam hal ini sangat dibutuhkan kemampuan mengendalikan emosi. Karenan tanpa kemampuan mengendalikan emosi, emosi akan dapat menjadi suatu penyakit yang dapat meresahkan hati serta menghilangkan kemampuan kita, sebagaimana Prof. Nasaruddin Umar, dalam pengantar buku M. Darwis Hude mengatakan, emosi yang kadang memiliki kekuatan menyembuhkan, yang kadang pula menjadi penyakit yang mematikan. Emosi yang tidak hanya mampu menghadirkan kenyamanan dan ketenangan, tapi juga menghadirkan keresahan yang luar biasa. ${ }^{18}$

M. Darwis Hude, dalam bukunya menyebutkan ada empat macam cara mengendalikan emosi yang sesuai dengan prinsipprinsip al-Quran. Pertama adalah model Displacement, yakni dengan cara mengalihkan atau menyalurkan ketegangan emosi pada obyek lain seperti Dzikrullah. Kedua, adalah model Cognitive adjusment (model pengalihan kognisi) seperti atribusi positif (Husn al-Zhann). Ketiga, model Coping, yaitu dengan menerima atau menjalani segala hal yang terjadi dalam hidup, seperti sabar. Keempat, yaitu model lain-lain seperti Regresi, yaitu salah satu bentuk mekanisme pertahanan diri dengan cara mundur dari perkembangan yang lebih tinggi ke yang lebih rendah. Dalam konteks al-Qur'an, taubat adalah salah satu dari bentuk regresi, yaitu kembali dari pelanggaran (maksiat) ke fitrah kesucian manusia. Selain itu ada lagi Represi dan Relaksasi. ${ }^{19}$

Berangkat dari problem tersebut maka penulis tertarik untuk mengkaji lebih jauh ayat-ayat al-Qur'an yang berkaitan dengan psikologi dan bagaimana cara yang diajarkan Allah swt. untuk mengendalikan emosi dalam surat Yūsuf.

\section{B. Bentuk Emosi dan Interpretasinya Dalam Surat Yusuf}

${ }^{17}$ Hendra Surya, Jadilah Pribadi Yang Unggul, hlm. 41

${ }^{18}$ M. Darwis Hude, Emosi Penjelajahan Religio-Psikologis, hlm. ix

${ }^{19}$ M. Darwis Hude, Emosi Penjelajahan Religio-Psikologis, hlm. 264, 270,278 
1. Emosi sedih.

Dalam surat Yusuf, emosi sedih digambarkan pada ayat 13, 16 dan 84. Ayat ke 13 ini mencakup emosi sedih dan takut.

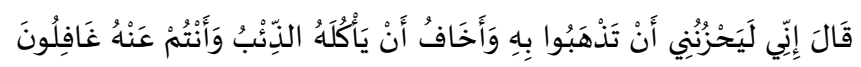

"Dia Ya'qūb brkata: "Sesungguhnya kepergian kamu bersama Yūsuf amat menyedihkanku dan aku khawatir kalau-kalau dia dimakan serigala, sedang kamu lengah dari padanya". ${ }^{20}$

Adapun penafsiran ayat tersebut sebagaimana dalam ayatnya (قال اني ليحزني ان تذهبوا به ) "Sesungguhnya kepergian kalian bersamannya (Yūsuf) sangat membuatku sedih", kalimat ini menggambarkan betapa besar cinta dan kasih sayang Ya'qūb kepada Yūsuf. $^{21}$ Namun, masalah itulah yang selama ini dipersoalkan saudara-saudara Yūsuf. Mereka cemburu dan dengki karena menganggap ayah mereka lebih mencintai Yūsuf dibanding mereka. Karena itulah mereka bersekongkol untuk menjauhkan Yūsuf dari ayah mereka. Ungkapan Ya'qūb itu sekan-akan menjadi isyarat nyata yang membuat mereka semakin berhasrat menjauhkan Yūsuf dari ayah mereka. ${ }^{22}$

Baqhawi, dalam Ma'lim Al-Tanzil, menafsirkan bahwa kesedihan yang dimaksud dalam ayat 13 surat Yūsuf adalah kesedihan hati karena berpisah dengan orang yang dicintai.

$$
\text { أي: يحزني ذهابكم به، والحزن ها هنا: ألم القلب بفراق المحبوب }
$$

Emosi sedih merupakan perasaan yang banyak dialami manusia. Sebagimana kesedihan Nabi Ya'qūb. Namun jika kesedihan itu semakin menguat maka semakin lama akan mengusik kondisi jiwa yang pada gilirannya akan mengganggu kondisi fisik. Salah satunya adalah penyakit yang oleh para ilmuan biasa disebut dengan istilah melankolik (murung). Ciri

20 Al-Hikmah, Al-Qur'an dan Terjemahnya I, diterjemahkan Oleh Penyelenggara Penterjemah Al-Qur'an dan disempurnakan Oleh Lajnah Pentashih Mushaf Al-Qur'an, (Bandung: Diponegoro, 2014), Cet. 10, hlm. 236

${ }^{21}$ Fuad Al-Aris, Tafsir Psikologi, hlm. 77

${ }^{22}$ Fuad Al-Aris, Tafsir Psikologi, hlm. 78

23 Baqhawi, Abu Muhamad Al-Husayn ibn'ûd Al-Farra', Ma'lim AlTanzil, dari Al-Maktabah Al-Syâmilah, Tafsir Surat Yūsuf Ayat: 13, (Bairut: Dar Ihya At-Tutars Al-‘Arabi, 1420), Jilid. 2, hlm. 479 
umumnya adalah kesedihan yang menguasai kesedihan seseorang sehingga memunculkan keinginan untuk bunuh diri. ${ }^{24}$

Kondisi jiwa dan kondisi fisik memang erat hubugannya, dan memang telah nyata adanya. Saat ini kalau kita saksikan dalam kehidupan sehari-hari, baik secara langsung ataupun melalui media-media, tidak jarang kita temui orang yang bunuh diri karena patah hati sebab diputuskan oleh kekasih hatinya. Orang terkena penyakit magh lantaran nafsu makannya telah hilang, akibat dari murung yang disebabkan karena putus cinta, hal demikan juga telah dicontohkan sejak lama oleh Allah swt. dalam al-Qur'an, sebagaimana kesedihan yang teramat mendalam yang dialami oleh Nabi Ya'qūb sehingga matanya menjadi putih, dan berujung pada kebutaan.

"dan aku khawatir kalau-kalau dia dimakan serigala, sedangkan kalian lengah darinya. (Yūsuf: 13)

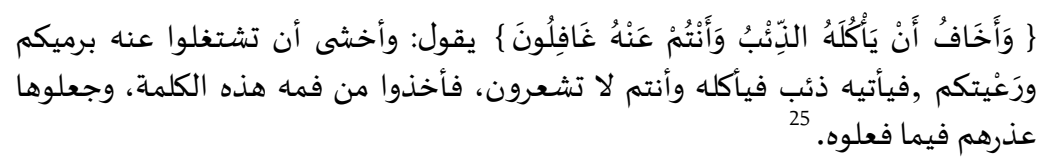

Nabi Ya'qūb mengatakan bahwa dirinya merasa takut apabila nanti anak-anaknya sibuk dengan permainan dan gembalaan mereka sehingga melupakan penjagaannya terhadap Yūsuf, lalu datanglah serigala memangsanya, sedangkan mereka tidak mengetahuinya. Mereka (saudara-saudara Yūsuf) menangkap pesan-pesan itu dari lisan ayah mereka dan mereka simpan di dalam hati mereka, kelak hal itu akan dijadikan sebagai alasan mereka dalam tindak kejahatannya.

Emosi takut dalam ayat ini ditekankan dalam kata أخاف yaitu takut yang dikarenakan kekhawatiran. Khawatir akan binatang buas yang pada saat itu memang banyak ada di daerah mereka. Sebagaimana penafsiran Jalaluddin al-Mahally dan Jalaluddin Asy-Syuyuti dalam ayat ini.

المراد باء الجنس وكانت أرضهم كثيرة الذئاب

${ }^{24}$ Fuad Al-Aris, Tafsir Psikologi, hlm. 79

${ }^{25}$ Abu Fida' Isma'il bin Katsir Al-Quraisyi Ad-Dimasyqi, Tafsir AlQur'an Al-Adzim, dari Al-Maktabah Al-Syâmilah, Surat Yūsuf Ayat: 13, (Bairut: Dar Al-Kutub Al-'Ilmiyah, 1419), Jilid. 4, hlm. 320 
Rasa keberatan dan kekhawatiran Ya'qūb untuk mengizinkan Yūsuf dibawa oleh saudara-saudaranya terlihat dari sisi gaya bahasa al-Qur'an dalam menggambarkan kejadian ini.

Ungkapan anak-anaknya dalam ayat yang ke 12, ارسله معنا غدا (biarkanlah ia pergi bersama kami besok pagi) ini mempergunakan bahasa persuasif "biarkanlah ia" frase ini mengandung makna perlindungan, harapan, kasih sayang dan ketundukan. Mereka menggunakan bahasa ini dengan tujuan agar Ya'qūb mengizinkan mereka membawa Yūsuf. Sementara ungkapan Ya'qūb yang mengizinkan dengan penuh kekhawatiran ان تذهبوا به diungkapkan dengan gaya bahasa yang berbeda (kepergian kalian bersamanya) seolah-olah ia ingin mengatakan, tindakan kalian itu sama saja artinya kalian ingin merenggutnya dariku. $^{27}$

Nabi Ya'qūb kemudian memberikan izin dengan berpegang pada janji mereka yang akan melindungi Yūsuf dari segala bentuk bahaya. Setelah mendapat izin untuk membawa Yūsuf, kegembiraan terpancar dari wajah saudara-saudara Yūsuf. Ketika akan berpisah, Nabi Ya'qūb terus memeluk dan menciumi Yūsuf serta mendoakan keselamatannya. ${ }^{28}$ Hal ini menggambarkan betapa sesungguhnya sangat berat Nabi Ya'qūb melepas Yūsuf pergi bersama saudara-saudaranya.

Ayat berikutnya adalah ayat 16 :

$$
\text { وَجَاءُوا أَبَاهُهُ عِشَاءً يَبْكُونَ }
$$

"Kemudian mereka datang kepada ayah mereka di sore hari sambil menangis". ${ }^{29}$

Ayat ini menggambarkan dengan jelas rangkaian peristiwa yang terjadi beserta kronologi waktunya. Frasa "sore hari ('isya')" pada ayat di atas menggambarkan rencana rapi yang telah disusun saudara-saudara Yūsuf untuk menjauhkan Yūsuf dan kemudian

26 Jalaludin Al-Mahally, Jalaludin Asy-Syuyuti, Tafsir Jalalain, dari Al-Maktabah Al-Syâmilah, Surat Yūsuf Ayat: 13, (Kairo: Dar Al-Hadits, t.th), Jilid. 1, hlm. 304

${ }^{27}$ Fuad Al-Aris, Tafsir Psikologi, hlm. 80

${ }^{28}$ M. Nasib ar-Rifa"i, Taisîrû al-Aliyyul Qadîr li Ikhtishâri Tafsîr Ibnu Katsir, terj. Syihabudin, (Jakarta: Gema Insani, 1999), hlm. 841

${ }^{29}$ M. Nasib ar-Rifaei, Taisîrû al-Aliyyul Qadîr li Ikhtishâri Tafsîr Ibnu Katsir, terj. Syihabudin, hlm. 237 
menyampaikan informasi itu kepada ayah mereka. Tentu saja kabar yang akan mereka sampaikan itu sangat mengejutkan dan pasti membuat Ya'qūb berduka. Mereka benar-benar telah menyusun semua langkah dengan rapi, termasuk menentukan kapan mereka akan menyampaikan kabar mengejutkan itu. Kebohongan yang mereka ungkapkan dari awal semakin dalam dibungkus dengan kebohongan-kebohongan lain. ${ }^{30}$

Kata Yabkūn dalam ayat di atas berasal dari buka yang artinya adalah mengalirnya air mata karena sedih. ${ }^{31}$ Sesunggunya, air mata yang bercucuran tidak selalu menggambarkan kesedihan. karena ada orang yang terharu dan mengeluarkan air mata ketika merasakan kegembiraan dan kebahagiaan. Karena baru-baru ini para ilmuan menemukan bahwa tangisan muncul setelah satu unsur atau senyawa dalam tubuh yang disebut endorphin lecune enkephalin dan prolactin dikeluarkan. Unsur ini seandainya dimasukkan kedalam darah manusia yang sedang gembira, pasti akan membuatnya menangis dan berlinang air mata. ${ }^{32}$ Ada juga mengeluarkan air mata hanya bermaksud untuk bersandiwara. Seperti ekspresi tangisan saudara-saudara Yūsuf setelah mereka membuang Yūsuf kedalam sebuah sumur. Sebagaimana ungkapan al-Alusi dalam Ruhul Ma'ani:

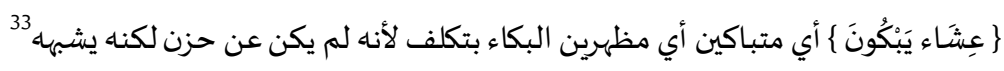

Orang yang menangis seperti ini biasanya berusaha keras mengeluarkan air mata namun terkadang tidak bisa, sehingga mendukungnya dengan mengeluarkan suara dan raut muka yang seolah-olah berduka. Karena tangisan itu pada dasarnya hanyalah ada pada orang yang sedang tersentuh hatinya bukan pada orang yang sedang bersandiwara.

Dalam ayat 84 menjelaskan tentang emosi sedih yang menyebabkan penyakit fisik.

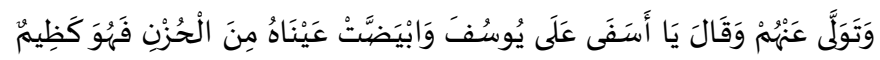

${ }^{30}$ Fuad Al-Aris, Tafsir Psikologi, hlm. 98

${ }^{31}$ Ibn Manzhūr, Lisan al-'Arab, Jilid 1, (Kairo, Dār al-Ma'ārif, t.th.), hlm. 337

${ }^{32}$ Fuad Al-Aris, Tafsir Psikologi, hlm. 97

33 Syihābudin Mahmūd Ibnu 'Abdullah Al-Husaini Al-alūsi, Ruhul Ma'ani Fi-Tafsiri Qur'an Al-Adzim, dari Maktabah Al-Syâmilah, Tafsir Surat Yūsuf Ayat: 16, (Bairut: Dar Al-Kutub Al-Ilmiyah, 1415), Jilid. 6, hlm. 391 
"Dan Ya'qūb berpaling dari mereka (anak-anaknya) seraya berkata: "Aduhai duka citaku terhadap Yūsuf", dan kedua matanya menjadi putih Karena kesedihan. Dia diam menahan amarah (terhadap anakanaknya)".

Ayat ini menjelaskan sebuah emosi sedih yang berdampak kepada kondisi fisik. Yakni suatu kesedihan yang dialami oleh Nabi Ya'qūb, yang menyebabkan kebutaan pada matanya.

Kata وتولى عَنْهم (berpaling dari mereka) dalam tafsir Ibnu Katsir, dijelaskan bahwa Nabi Ya'qūb berpaling dari anakanaknya dan berkata, sambil teringat kembali kesedihan pertama yang sudah lama.

$$
\text { أعرض عن بنيه وقال متذكرا حُزنَ يوسف القديم الأول }
$$

Nabi Ya'qūb berpaling dari anak-anaknya bertujuan untuk menunjukkan bahwa ia adalah seorang manusia biasa yang memiliki gejolak perasaan. Ia tidak dapat mengingkari gejolak perasaannya ketika menghadapi kondisi yang sangat berat dan menyedihkan. ${ }^{35}$

Kata (Aduhai duka citaku) dalam ayat diatas bermakna suatu kesedihan yang teramat sangat mendalam yang disertai penyesalan, sebagaimana ungkapan At-Thabary dalam tafsirnya:

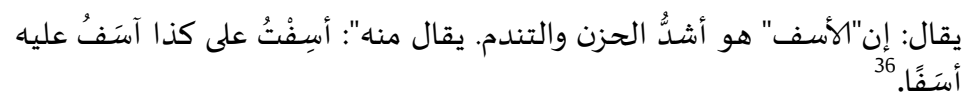

Kata وابيضت عَيْنَاه (dan kedua matanya menjadi putih) dalam Tafsir Jalalain ditafsirkan bahwa bagian yang hitam dari mata Nabi Ya'qūb tertutup oleh benda yang putih karena terlalu banyak menangis, disebabkan oleh kesedihan yang dialaminya lantaran kehilangan anak yang sangat dicintainya, yaitu Yūsuf. Dan sesungguhnya, pada saat itu Nabi Ya'qūb sedang berada dalam keadaan marah pada anak-anaknya. Namun Nabi Ya'qūb berusaha menahannya.

${ }^{34}$ Abu Fida' Isma'il bin Katsir Al-Quraisyi Ad-Dimasyqi, Tafsir AlQur'an Al-Adzim, Surat Yūsuf Ayat: 84, Jilid. 4, hlm. 347

${ }^{35}$ Fuad Al-Aris, Tafsir Psikologi, hlm. 460

${ }^{36}$ At-Thabari, Jami'ul Bayan Fi Ta'wil Qur'an, Surat Yūsuf Ayat: 84, Jilid. 16, hlm. 215 


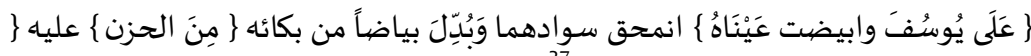

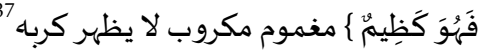

Fuad al-Aris mengatakan bahwa kesedihan yang dialami Nabi Ya'qūb, adalah kesedihan yang intensitasnya meningkat, dilihat dari ekspresi pertama, yaitu memalingkan muka dari anakanaknya hingga gambaran kesedihan yang memuncak, yaitu memutih bola matanya. ${ }^{38}$

Urutan seperti ini, sangat sering dialami oleh kebanyakan manusia yang sedang mengalami kesediahan. Yang biasanya dialami oleh orang-orang yang ditimpa musibah berganti-ganti dalam waktu yang relatif singkat.

2. Emosi marah terdapat pada ayat 77 :

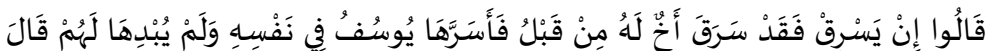

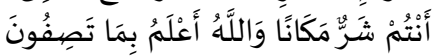

"Mereka berkata: Jika ia mencuri, maka sungguh, sebelum itu saudaranyapun pernah pula mencuri. Maka Yūsuf menyembunyikan kejengkelan dalam hatinya, dan tidak ditampakkan kepada mereka. dia berkata (dalam hatinya): kedudukanmu justru lebih buruk, dan Allah swt. Maha mengetahui apa yang kamu terangkan".

Dalam tafsirnya, Quraish Shihab mengemukakan bahwa saudara-saudara Yūsuf tidak mempercayai bahwa Bunyamin telah mencuri, namun untuk menutup malu mereka berkata 'jika ia', yakin bahwa Bunyamin bener-benar mencuri. Hal ini dipahami dari kata ان (jika). Saudara-saudara Yūsuf berkata bahwa keburukan sifat ini menurun dari keburukan ibunya. Karena pernah pula mencuri saudara kandungnya, yaitu Yūsuf yang mereka maksud. ${ }^{39}$

Tuduhan ini adalah tuduhan dusta dan sangat tidak bertanggung jawab, karena sesungguhnya Yūsuf tidak pernah mencuri, sebagaimana ungkapan Hamka dalam tafsirnya, beliau mengatakan bahwa penafsiran yang menyebutkan, Yūsuf diwaktu

${ }^{37}$ Jalaluddin Mahalliy, Jalaluddin Asy-Syuyuthi, Surat Yūsuf Ayat: 84, Jilid. 1, hlm. 316

${ }^{38}$ Fuad Al-Aris, Tafsir Psikologi, hlm. 467

39 M. Quraish Shihab, Tafsir al-Mishbāh, Pesan, Kesan, dan Keserasian al-Qur'an, Vol. 6, (Jakarta: Lentera Hati, 2001), hlm. 504 
kecil pernah mencuri, adalah penafsiran yang ganjil. ${ }^{40}$ Quraish Shihab juga berpendapat bahwa tuduhan terhadap Yūsuf yang pernah mencuri, adalah sebuah tuduhan yang sengaja dilontarkan untuk menutupi keburukan sikap mereka. dan juga menunjukan masih adanya sisa-sisa kedengkian mereka terhadap Yūsuf. ${ }^{41}$ Yūsuf yang mendengar ucapan tersebut juga merasa sangat jengkel, tetapi dia menyembunyikan kejengkelannya pada dirinya dan sama sekali tidak menampakkannya kepada mereka. ${ }^{42}$

Menurut Fuad al-Aris, keadaan ini benar-benar menggambarkan jiwa saudara-saudara Yūsuf yang sedang panik, marah, dan gelisah. Serta merta mereka melemparkan tuduhan terhadap Yūsuf pernah mencuri. Padahal, tuduhan dan fitnah yang mereka lontarkan tidak memengaruhi hukuman yang harus dijalani adik mereka. Ungkapan itu menggambarkan apa yang selama ini mereka sembunyikan dalam dada mereka, yaitu kedengkian kepada Yūsuf ungkapan spontan itu hanya akan terlontar dalam situasi semacam itu. ${ }^{43}$

Dalam kajian psikologis, hal ini menunjukan bahwa bisa jadi lawan bicara kita menyimpan kebencian kepada kita dengan menampakan kelembutan dan kasih sayang. Ia bisa terus menampakan perasaan kasih sayang itu selama masih bisa megendalikan kesadaran dan gejolak perasaannya. Namun dalam keadaan marah besar atau tersudutkan, kendali jiwa itu melemah sehingga membuka peluang bagi munculnya perasaan yang selama ini ditahan dan disembunyikan. Kebencian yang disembunyikan itu muncul baik dalam bentuk pengingkaran spontan, ketergelinciran lisan, menunjukan sikap yang tidak layak, sekedar berpaling, atau menunjukan rasa kesal. ${ }^{44}$

Keadaan yang sedang dialami Yūsuf pada ayat diatas adalah sebuah emosi marah yang tidak ditampakkan. Hal ini dijelaskan

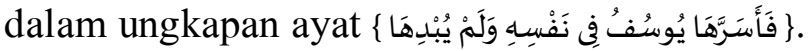

Dalam Tafsir Jalalain, dijelaskan bahwa Nabi Yūsuf menyembunyikan kejengkelan itu pada dirinya dan tidak

\footnotetext{
${ }^{40}$ Hamka, Tafsîr Al-Azhar, Juz. 13, hlm. 28

${ }^{41}$ M. Quraish Shihab, Tafsir al-Mishbāh, hlm. 505

${ }^{42}$ M. Quraish Shihab, Tafsir al-Mishbāh, hlm. 504

${ }^{43}$ Fuad Al-Aris, Tafsir Psikologi, hlm. 425

${ }^{44}$ Fuad Al-Aris, Tafsir Psikologi, hlm. 425
} 
melahirkannya kepada saudara-saudaranya. Nabi Yūsuf hanya berkata di dalam hatinya, bahwa mereka lebih hina daripada Yūsuf dan saudara sekandungnya karena mereka telah mencuri saudara mereka sendiri, yaitu Nabi Yūsuf dari tangan ayah mereka, kemudian mereka berbuat aniaya terhadap dirinya.

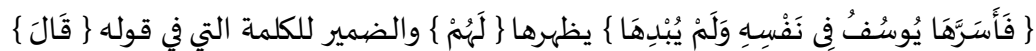

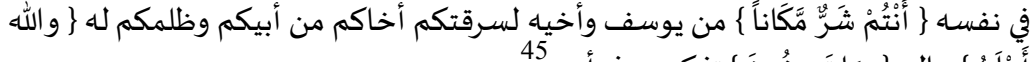

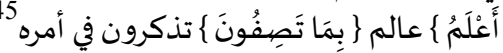

3. Emosi bahagia terdapat dalam ayat 96 :

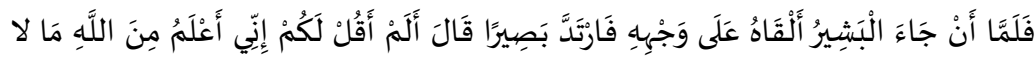
تَعْلَمُونَ فَمَنَ

"Maka ketika telah tiba pembawa kabar gembira itu, Maka diusapkan baju gamis itu ke wajah Ya'qūb, lalu dia dapat melihat kembali. Dan Ya'qūb berkata: "Bukankah telah aku katakan kepadamu, bahwa aku mengetahui dari Allah swt. apa yang kamu tidak ketahui".

Dalam Tafsir Jalalain dijelaskan bahwa yang membawa kabar gembira kepada Nabi Ya'qūb adalah Yahudza dengan membawa baju gamis Nabi Yūsuf. Karena dahulu dialah yang membawa baju darah Nabi Yūsuf, maka kali ini ia bermaksud untuk membuat bahagia ayahnya sebagai ganti daripada perbuatannya dahulu yang membuat Nabi Ya'qūb sedih. Kemudian setelah baju gamis itu diusapkan pada wajah Nabi Ya'qūb, ia sehat dan bisa melihat seperti semula.

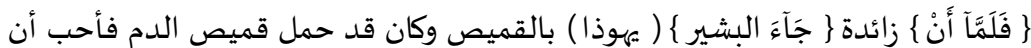

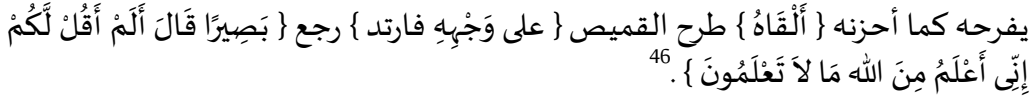

Pendapat di atas juga diungkapkan oleh Ibnu Katsir, beliau mengutip riwayat Mujahid dan As-Suddi, yang mengatakan bahwa pembawa kabar gembira itu adalah Yahudza Bin Ya'qūb. Ia melakukan ini karena dahulu ia yang membawa baju gamis

${ }^{45}$ Jalaluddin Mahalliy, Jalaluddin Asy-Syuyuthi, Surat Yūsuf Ayat: 77, Jilid. 1, hlm. 315

${ }^{46}$ Jalaluddin Mahalliy, Jalaluddin Asy-Syuyuthi, Surat Yūsuf Ayat: 96, Jilid. 1, hlm. 318 
Yūsuf yang dilumuri darah palsu, dan dengan cara ini ia ingin membersihkan dirinya dari kesalahannya dahulu.

$$
\begin{aligned}
& \text { وقال مجاهد والسدي: كان يهوذا بن يعقوب.قال السدي: إنما جاء باه لأنه هو الذي جاء }
\end{aligned}
$$

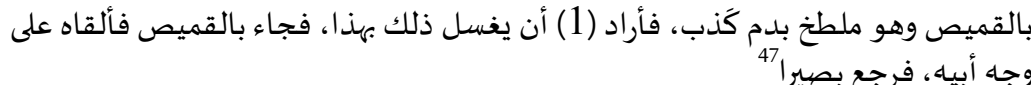

Peristiwa itu menjadi bukti tingginya kedudukan Ya'qūb di sisi Allah swt. Seandainya orang biasa yang mengalami kejadian seperti itu, tentu ia akan senang bukan kepalang. Namun, Ya'qūb tidak lupa diri. Ia bersyukur kepada Allah swt atas kemurahanNya yang besar. Ia mendatangi keluarganya sebagai orang yang memberikan nasihat, dakwah dan pelajaran. ${ }^{48}$

Hal ini juga telah membuktikan bahwa sakit yang dialami Nabi Ya'qūb bukanlah sakit karena keadaan beliau yang sudah tua, namun sakit yang ia alami akibat dari kesedihan dan duka cita yang beliau alami bertahun-tahun.

\section{Pesan Allah Dalam Surat Yusuf}

Setelah peneliti menelaah lebih jauh, sekurang-kurangnya ditemukan tiga cara dalam mengendalikan emosi yang diajarkan Allah dalam surat Yūsuf, yakni sabar, memaafkan, dan dzikrullah, baik secara implisit maupun eksplisit, yang terdapat dalam enam ayat, yaitu ayat 18, 83, 86, 92, 97, dan 98 .

Sabar dan memaafkan dalam kajian emosi termasuk dalam cara pengendalian emosi model Coping, yang artinya menerima atau menjalani segala hal yang terjadi dalam kehidupan. ${ }^{49}$ Sedangkan dzikrullah termasuk dalam model pengendalian (Displacement) yaitu model pengendalian dengan cara mengalihkan emosi. ${ }^{50}$

1. Sabar

Dalam surat Yūsuf ini, kata sabar disebutkan dua kali, dengan redaksi yang sama, namun dengan kasus yang berbeda yaitu dalam ayat 18 dan 83 :

${ }^{47}$ Abu Fida' Isma'il bin Katsir Al-Quraisyi Ad-Dimasyqi, Tafsir AlQur'an Al-Adzim, Surat Yūsuf Ayat: 96, Jilid. 4, hlm. 351

${ }^{48}$ Fuad Al-Aris, Tafsir Psikologi, hlm. 511

${ }^{49}$ M. Darwis Hude, Emosi Penjelajahan Religio-Psikologis, hlm. 259

${ }^{50}$ M. Darwis Hude, Emosi Penjelajahan Religio-Psikologis, hlm. 257 


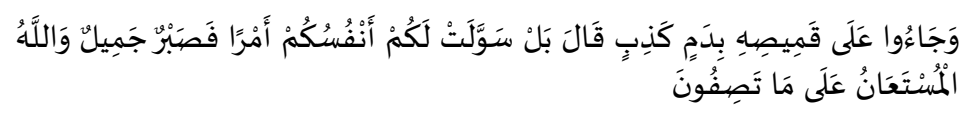

"Dan mereka datang membawa baju gamisnya (yang berlumuran) dengan darah palsu. Ya'qūb berkata: "Sebenarnya dirimu sendirilah yang memandang baik perbuatan (yang buruk) itu; Maka hanya bersabar yang baik Itulah kesabaranku. Dan kepada Allah saja memohon pertolongan-Nya terhadap apa yang kamu ceritakan”.

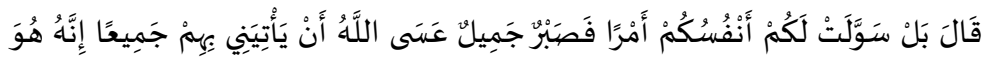

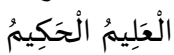

"Ya'qūb berkata: Sebenarnya hanya dirimu sendiri yang memandang baik perbuatan (yang buruk) itu. Maka kesabaran yang baik Itulah (kesabaranku). Mudah-mudahan Allah mendatangkan mereka semuanya kepadaku; Sesungguhnya Dia-lah yang Maha mengetahui lagi Maha Bijaksana".

Kalimat فصبر جميل ini diucapakan Nabi Ya'qūb tatkala kehilangan dua anak yang dicintainya, yaitu Yūsuf dan Bunyamin. Ibnu Katsir menafsirkan kalimat فصبر جميل, yang terdapat pada ayat 18, bahwa Nabi Ya'qūb melakukan kesabaran, dengan sebaik-baiknya kesabaran. Dan Nabi Ya'qūb hanya mengharapkan pertolongan dari Allah swt. atas ujian yang beliau hadapi.

فسأصبر صبرًا جميلا على هذا الأمر الذي قد اتفقتم عليه، حتى يفرجاء الله بعونه ولطفه 51

Keadaan Nabi Ya'qūb ini menggambarkan betapa beliau benar-benar orang yang mampu mengendalikan emosinya dengan kesabaran yang luar biasa. Ditegaskan pula dalam tafsir Jalalain bahwa kesabaran yang dilakukan Nabi Ya'qūb adalah kesabaran yang tidak disertai rasa gelisah.

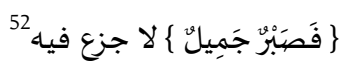

Nabi Ya'qūb tidak mencela anak-anaknya atas perbuatan yang mereka lakukan, beliau memilih berserah diri kepada Allah swt. dan meminta petunjuk atas kebenaran kabar cerita dari anakanaknya, yaitu mengenai perkara Yūsuf, sebagaimana dijelaskan dalam tafsir Jalalain.

51 Abu Fida' Isma'il bin Katsir Al-Quraisyi Ad-Dimasyqi, Tafsir AlQur'an Al-Adzim, Surat Yūsuf Ayat: 18, Jilid. 4, hlm. 322

52 Jalaludin Al-Mahally, Jalaludin Asy-Syuyuti, Tafsir Jalalain, Surat Yūsuf Ayat: 18, Jilid. 1, hlm. 305 
53 والله المستعان \{ المطلوب منه العون \} على مَا تَصِفُونَ \{ تذكرون من أمر يوسف

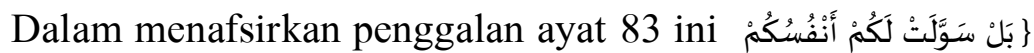
أَمْرًا فَصَبْبُ جَمِيلِ menyangka anak-anaknya melakukan kebohongan sebagiamana dahulu pernah dilakukannya saat membuang Yūsuf, sehingga Nabi Ya'qūb pun berkata sama.

$$
\begin{aligned}
& \text { قال لهم كما قال لهم حين جاءوا على قميص يوسف بدم كذب: جَّلْ سَوَََّتْ لَكُمْ }
\end{aligned}
$$

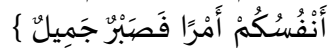

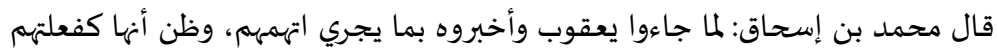

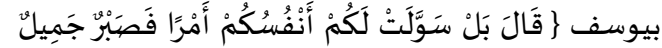

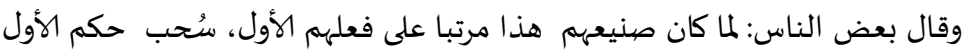

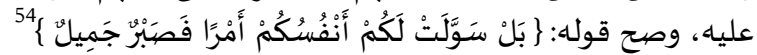

Ketidakpercayaan Nabi Ya'qūb adalah suatu kewajaran walau sebenarnya cerita itu benar-benar terjadi, karena sebelumnya mereka pernah berbohong, secara naluri memang susah percaya kepada orang yang sebelumnya pernah berbohong, selain itu karena Ya'qūb memang tidak dibukakan pengetahuan gaib agar dapat melihat kebenaran cerita anak-anaknya itu, sebagaimana pernah diberikan Allah swt. saat kehilangan Yūsuf dahulu.

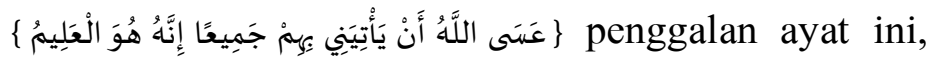
ditafsirkan oleh Ibnu Katsir bahwa Ya'qūb berharap semua anakanaknya kembali, yaitu Yūsuf dan kedua saudaranya, namun beliau hanya berserah terhadap takdir Allah swt. atas keadaannya sekarang.

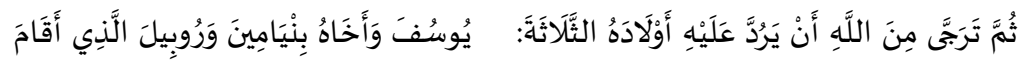

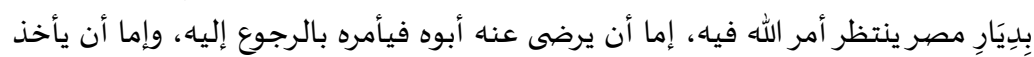
أخحاه خفيةُ؛ ولهذا قال:

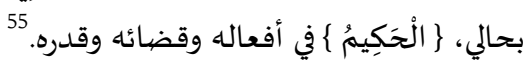

Kalau kita pahami, ungkapan ayat di atas menggunakan lafadz جَمِيعًا artinya banyak atau lebih dari dua, padahal yang

${ }^{53}$ Tafsir Jalalain, Jilid. 1, hlm. 305

54 Abu Fida' Isma'il bin Katsir Al-Quraisyi Ad-Dimasyqi, Tafsir AlQur'an Al-Adzim, Surat Yūsuf Ayat: 83, Jilid. 4, hlm. 346

55 Abu Fida' Isma'il bin Katsir Al-Quraisyi Ad-Dimasyqi, Tafsir AlQur'an Al-Adzim, Surat Yūsuf Ayat: 83, Jilid. 4, hlm. 347 
disebutkan dalam peristiwa tersebut adalah Bunyamin dan Rubail sebagai kakak tertua, namun Allah swt. menggunakan kalimat Jama' bukan Tasniyah ini menguatkan bahwa sesungguhnya Ya'qūb tetap percaya dan mempunyai keyakinan bahwa Yūsuf masih hidup dan akan segera kembali.

Pada akhir ayat 83 di atas ditutup dengan ungkapan إنَّنُهُ هُوَ الْعَلِيمُ الْحَكِيمُ (Dia-lah yang Maha Mengetahui lagi Maha Bijaksana) bukan dengan ungkapan Maha Mendengar dan Maha Mengetahui, ini menjelaskan bahwa Nabi Ya'qūb tidak meminta agar dibukakan pengetahuan ghaib untuk mengetahui keadaan anakanaknya, melainkan beliau menyerahkan semua urusannya kepada Allah swt. dengan bertawakal, bahwa hanya Allah swt. yang memiliki hikmah dan kebijaksanaan yang mutlak atas segala ujian yang sedang beliau hadapi. ${ }^{56}$

Ayat 18 dan 83 di atas memberi pelajaran yang sangat berguna dalam kehidupan sehari-hari, agar kita tidak terburu-buru meluapkan emosi ketika tidak mempercayai suatu kabar atau cerita. Yang harus pertama kali dilakukan adalah merenungkan sejenak sebelum mengambil keputusan mengenai bagaimana seharusnya menentukan sikap. ${ }^{57}$

Sabar yang dilakukan Nabi Ya'qūb bukan sekedar sabar biasa, yang hanya mudah diucapkan lisan, karena kalau kita pahami redaksi ayat 83 tersebut menjelaskan runtutan kesabaran Nabi Ya'qūb yang luar biasa, setelah Nabi Ya'qūb berkata tentang kesabarannya, beliau berdoa hanya kepada Allah swt. agar dikembalikan ketiga puteranya, setelah itu beliau menyatakan kepasrahan dirinya atas takdir dan kehendak Allah swt.

Kata sabar di dalam al-Qur'an disebut 103 kali, baik dengan redaksi kata benda atau kata kerja, tersebar di dalam 46 surah, (29 surah Makiyyah dan 17 surah Madaniyyah), dan 101 ayat. $^{58}$

Secara bahasa sabar berasal dari kata ( صببر يصبر صبر), yang memiliki arti bersabar tabah hati, berani. ${ }^{59}$ Dalam Kamus Besar

${ }^{56}$ Fuad Al-Aris, Tafsir Psikologi, hlm. 107

${ }^{57}$ Fuad Al-Aris, Tafsir Psikologi, hlm. 457

${ }^{58}$ Muhammad Fu'ad Abd al-Baqi, al-Mu'jam al-Mufahras li alfadhzi Al-Qur'an, (Cairo: Dar al-Kutub al-Mishriyah, 1364 H), hlm. 400-401

59 Mahmud Yunus, Kamus Arab-Indonesia, (Jakarta: Yayasan Penyelenggara Penterjemah atau Penafsiran Al-Qur'an), hlm. 211 
Bahasa Indonesia, sabar diartikan dengan (tidak lekas marah, tidak lekas putus asa, tidak lekas patah hati) semakna dengan tabah. ${ }^{60}$

Secara terminologi menurut Ibnu Qayyim Al-Jauziyah, sabar adalah menahan jiwa dari cemas, menahan lisan dari mengeluh, dan menahan organ tubuh dari mencelakai diri, seperti menampar pipi, merobek-robek baju dan lain sebagainya. ${ }^{61}$

Allah swt. memang akan menguji orang-orang yang sabar dengan sedikit ketakutan, kelaparan, kekurangan harta dan jiwa, sebagaimana firman Allah swt. dalam QS. Al-Baqarah: 155-157:

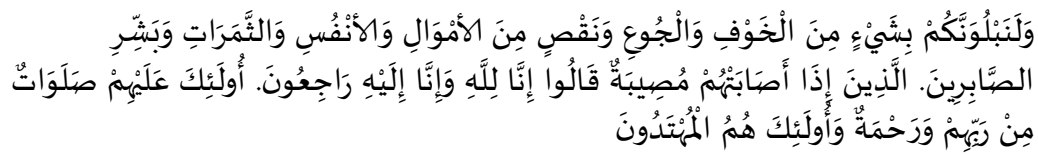

"Dan pasti kami akan menguji kamu dengan sedikit ketakutan, kelaparan, kekurangan harta, jiwa dan buah-buahan. dan sampaikan kabar gembira kepada orang-orang yang sabar (155), (yaitu) orangorang yang apabila ditimpa musibah, mereka mengucapkan: "Inna lillaahi wa innaa ilaihi raaji'uun. (156), Mereka Itulah yang mendapat ampunan dan rahmat dan rahmat dari Tuhannya dan mereka Itulah orang-orang yang mendapat petunjuk".

Kesabaran Nabi Ya'qūb layaknya kesabaran para Rosul Ulul 'azmi walau secara kenyataan Nabi Ya'qūb tidak termasuk golongan Ulul 'azmi namun secara karakter, kesabaran Nabi Ya'qūb tidak jauh dari mereka para Ulul 'azmi. Karena secara etimologis Ulul 'azmi berasal dari dua suku kata ulu dan 'azmi. Ulu mempunyai arti yang empunya (untuk bentuk jamak) serta 'azmi berasal dari kata 'azama yang mempunyai arti kemauan yang teguh dan kuat. ${ }^{62}$ Dengan kata lain Ulul 'azmi adalah mereka yang memiliki keteguhan hati dan ketabahan dalam menghadapi kesulitan serta tekad yang membaja untuk mewujudkan kebaikan. Sebagaimana firman Allah swt. dalam QS. Al-Ahqaf: 35:

${ }^{60}$ Depdikbud, Kamus Besar Bahasa Indonesia, (Jakarta: Balai Pustaka, 1990), hlm. 763

${ }^{61}$ Ibnu Qayyim Al-Jauziyah, Sabar Perisai Seorang Mukmin, Terj, Fadh, (Jakarta: Pustaka Azzam, 2002), hlm. 12

62 A.W. Munawwir, Kamus Al-Munawwir, (Surabaya: Pustaka Progresif, 1997), hlm. 928 


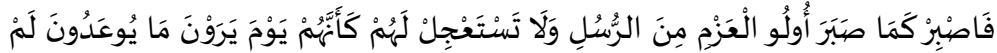

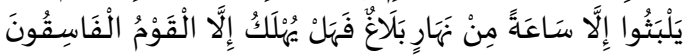

"Maka Bersabarlah kamu seperti orang-orang yang mempunyai keteguhan hati dari rasul-rasul Telah bersabar dan janganlah kamu meminta disegerakan (azab) bagi mereka. pada hari mereka melihat azab yang diancamkan kepada mereka (merasa) seolah-olah tidak tinggal (di dunia) melainkan sesaat pada siang hari. Tugasmu hanya menyampaikan, maka tidak ada yang dibinasakan kecuali kaum yang fasik (tidak taat kepada Allah)".

\section{Memaafkan}

Dalam surat Yūsuf ditemukan ada empat ayat yang membicarakan tentang maaf dan memaafkan, yaitu ayat 91, 92, 97, dan 98.

Dalam ayat 91 ini dijelaskan pengakuan saudara-saudara Yūsuf atas kesalahanya. Dan dalam ayat selanjutnya dijelaskan betapa lembutnya sikap Nabi Yūsuf yang ikhlas memberi maaf terhadap saudara-saudaranya atas perbuatan dzalim yang pernah mereka perbuat dahulu.

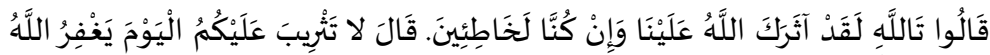

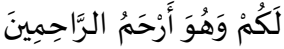

"Mereka berkata: "Demi Allah, Sesungguhnya Allah Telah melebihkan kamu atas kami, dan Sesungguhnya kami adalah orangorang yang bersalah (berdosa)" (91), Dia (Yūsuf) berkata: "Pada hari Ini tak ada cercaan terhadap kamu, Mudah-mudahan Allah mengampuni (kamu), dan dia adalah Maha Penyayang diantara para penyayang".

Pada ayat diatas dijelaskan قَالُوا تَاللَّهِ لَقَدْ آَثَرَكَ اللَّهُ عَلَيْنَا (Demi Allah, Sesungguhnya Allah telah melebihkan kamu atas kami) ungkapan saudara-saudara Yūsuf ini menggambarkan keikhlasan dan ketulusan dalam memuji. Mereka berkata bahwa Allah swt. melebihkanmu dari kami. Kelebihan yang ada pada diri Yūsuf diantaranya adalah pengetahuan, kesantunan, kecerdasan, kemuliaan, kesabaran, ketampanan, sikap ihsan, dan kekuasaan. ${ }^{63}$

Kemudian kalimat وَإِنْ كُنَّا لَخَاطِئينَ (dan Sesungguhnya kami adalah orang-orang yang bersalah) dalam ungkapan tersebut

${ }^{63}$ Fuad Al-Aris, Tafsir Psikologi, hlm. 492 
terkandung pengakuan bersalah sekaligus permohonan agar dimaafkan dan diampuni. Mereka benar-benar mencela dan mengecam perbuatan mereka sendiri. Mereka juga tidak mencari dalih dan alasan untuk perbuatan yang telah mereka lakukan, mereka dengan jantan mengakui kesalahan dan kedzaliman mereka, seraya mengharapkan rahmat Allah swt. ${ }^{64}$

Jika kita perhatikan cara meminta maaf yang dilakukan oleh saudara-saudara Yūsuf adalah sangat indah. Mereka meminta maaf dengan akhlak yang mulia. Mula-mula mereka mengungkapkan pujian terlebih dahulu kepada orang yang pernah mereka dzalimi kemudian mengakui kesalahannya serta meminta maaf.

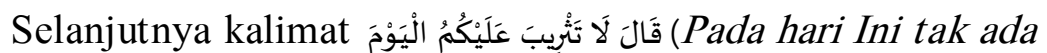
cercaan terhadap kamu) secara harfiyah kata تَنِْْيَّ bermakna menghilangkan lemak atau minyak yang menutupi perut. Kata itu mengacu pada celaan atau kecaman yang merusak kehormatan, dan membuka aib seseorang. ${ }^{65}$ Maka Yūsuf menggunakan kata ini, dengan tujuan bahwa Yūsuf benar-benar tidak memiliki rasa dendam terhadap saudara-saudaranya.

يغفر الله لكم (mudah-mudahan Allah mengampunimu) kalimat ini bermakna do'a. Artinya aku mendoakan agar Allah swt. memberi ampun pada kalian. Hal ini menegaskan bahwa Yūsuf tidak mau menuntut haknya untuk balas dendam. Sebaliknya beliau memaafkan mereka dan kemudian berdo'a agar Allah swt. juga memberikan ampunan kepada mereka. ${ }^{66}$ Karena sesungguhnya setiap manusia yang berhati baik tidak memiliki ruang untuk dendam dan pada momen kemenangannya beliau menunjukkan penuh kebaikan kepada saudara-saudaranya dan dengan penuh kerendahan hati terhadap tuhannya. ${ }^{67}$

Kemudian pada ayat 98 adalah permohonan maaf anak-anak Ya'qūb terhadap Ya'qūb, Allah swt. berfirman:

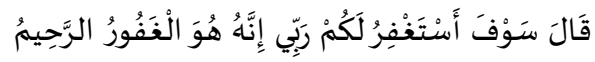

${ }^{64}$ Fuad Al-Aris, Tafsir Psikologi, hlm. 493

${ }^{65}$ Fuad Al-Aris, Tafsir Psikologi, hlm. 489

${ }^{66}$ Fuad Al-Aris, Tafsir Psikologi, hlm. 494

${ }^{67}$ Syeh Muhammad Ghazali, Tafsir Tematik Dalam Al-Qur'an, trj, Qodirun Nur, dan Ahmad Musyafiq, (Jakarta: Gaya Media Pratama, 2005), hlm. 213 
"Mereka berkata: "Wahai ayah kami, mohonkanlah ampun bagi kami terhadap dosa-dosa kami, Sesungguhnya kami adalah orang-orang yang bersalah (berdosa)".

Kalimat اسنتَغْفِرََْنَا ذُنُبَنَا (mohonkanlah ampun bagi kami terhadap dosa-dosa kami). Pada ayat di atas terlihat bahwa saudara-saudara Yūsuf telah mengakui kesalahanya dan ingin membersihkan jiwa mereka dengan meminta maaf dan ampunan kepada orang yang mereka perlakukan dengan buruk, yaitu ayahnya sendiri. Ungkapan ayat di atas meliputi dua bentuk permintaan ampunan, yaitu kepada Allah swt. dan kepada Ya'qūb. Hal seperti ini merupakan cara yang indah dalam meminta maaf. Dan juga menunjukkan kecerdasan dan kebeningan jiwa mereka. ${ }^{68}$

Mereka telah mengakui bahwa mereka telah melakukan banyak dosa dan kesalahan. Karena itulah lafadz yang digunakan di sini adalah ذَنُوَنَّ, mereka mengatakan: "mintakanlah ampunan atas dosa-dosa (dzunuub) kami”. Sementara, yang kita ketahui dari kisah ini dosa mereka hanya satu yaitu melemparkan Yūsuf ke dalam sumur.

Hal serupa juga diungkapkan oleh At-Thabari, beliau menyatakan bahwa anak-anak Ya'qūb telah mengakui, merekalah yang memisahkan antara Ya'qub dan Yūsuf, sehingga mereka meminta maaf atas semua dosa-dosa yang pernah dilakukan, diantaranya dosa kepada Yūsuf dan kepada Ya'qūb.

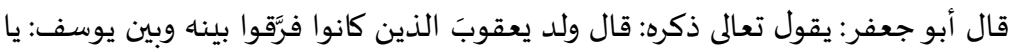

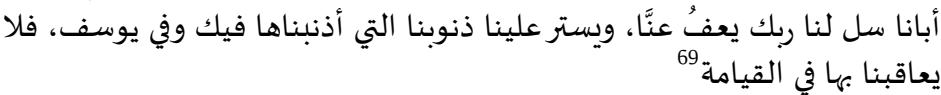

Fuad Al-Aris mengatakan bahwa ada sekitar delapan dosa yang mereka lakukan: ${ }^{70}$

1) Mereka bersekongkol merencanakan pembuangan Yūsuf

2) Ketika menunjukkan rasa cinta kepada Yūsuf dihadapan sang ayah, padahal sebetulnya mereka sangat membencinya

${ }^{68}$ Fuad Al-Aris, Tafsir Psikologi, hlm. 512

${ }^{69}$ At-Thabari, Jami'ul Bayan Fi Ta'wil Qur'an, Surat Yūsuf Ayat: 97, Jilid. 16, hlm. 261

${ }^{70}$ Fuad Al-Aris, Tafsir Psikologi, hlm. 523 
3) Ketika membawa Yūsuf dan mengatakan akan menjaganya, sementara niat sesungguhnya adalah untuk menumpahkan darah

4) Mereka lakukan saat melempar seorang anak kecil yang lemah ke dalam gelap sumur

5) Ketika datang menjumpai Ya'qūb sambil membawa baju yang sudah dilumuri darah

6) Dusta yang mereka katakan kepada Ya'qūb bahwa Yūsuf telah dimakan serigala

7) Ketika berada dihadapan al-Aziz mereka menuduh Yūsuf telah mencuri

8) Dosa kedelapan dan ini yang paling berat adalah duka mendalam yang dialami ayah mereka hingga akhirnya kehilangan penglihatan akibat dari perbuatan mereka.

Kemudian dalam ayat 98 :

قَالَ سَوْوفَ أَسْتَفْفِرُ لَكُمْ رَبِّيَ إِنَّهُ هُوَ الْغَفُورُ الرَّحِيمُ

"Ya'qūb berkata: "Aku akan memohonkan ampun bagimu kepada Tuhanku. Sesungguhnya Dia-lah yang Maha Pengampun lagi Maha penyayang".

Pada ayat di atas terkesan tidak ada kata-kata Ya'qūb, bahwa beliau memaafkan anak-anaknya. Namun sebagai seorang ayah dan juga Nabi utusan Allah swt., tentu saja dengan penuh kelembutan dan kasih sayang Ya'qūb memaafkan anak-anaknya. Ya'qūb menyampaikan maafnya tidak secara langsung, tetapi secara implisit dalam ucapannya yang indah. Sungguh Dia Maha Pengampun Dan Maha Penyayang.

Pernyataan Ya'qūb dalam ayat di atas menegaskan, bagaimana mungkin beliau tidak memaafkan anak-anaknya sementara beliau berdo'a dan bermunajat kepada Allah swt. dalam kondisi terbaiknya agar Allah swt. mengampuni dan menyayangi mereka. $^{71}$

Ya'qūb menunda untuk memintakan ampunan bagi anakanaknya. Seperti yang diketahui, tindakan buruk yang mereka lakukan kepada Ya'qūb lebih menyakitkan daripada yang

${ }^{71}$ Fuad Al-Aris, Tafsir Psikologi, hlm. 514 
dilakukan kepada Yūsuf yaitu siksaan terhadap jiwa lebih sakit daripada siksaan terhadap tubuh. Sementara kasih sayang seorang ayah kepada anaknya lebih besar daripada kasih sayang seseorang kepada saudaranya. Harapan Ya'qūb agar anak-anaknya mendapat ampunan tidak diwujudkan dengan sekedar meminta. Ia rela melakukan apapun agar anak-anaknya diampuni oleh Allah swt. Itulah keinginan dan perhatian besar seorang ayah kepada anakanaknya. Ia ingin berada dalam kondisi tenang dan sunyi ${ }^{72}$

Baqhawi dalam tafsirnya meyebutkan ada dua poin do'a yang dipanjatkan Nabi Ya'qūb. Pertama meminta ampunan atas kekhawatiran terhadap Yūsuf, beliau meminta diberi sedikit kesabaran. Kedua beliau meminta maafkan anak-anaknya terhadap apa yang telah mereka perbuat terhadap Yūsuf.

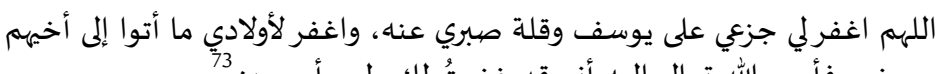

$$
\begin{aligned}
& \text { يوسف، فأوحى الله تعالى إليه أني قد غفرتُ لك ولهيه أجمعين }
\end{aligned}
$$

Islam sebagai agama yang dibawa oleh Nabi Muhammad saw, senantiasa mengajarkan perlunya mengendalikan amarah dan mengutamakan kemudahan memberi maaf kepada orang lain. Menahan amarah bukan berarti menyimpannya untuk sewaktuwaktu diletupkan, tetapi meleburnya dengan pemberian maaf. ${ }^{74}$

Memaafkan berasal dari kata maaf yang mendapat imbuhan me-kan, yang berarti ampun mengapuni. ${ }^{75}$ Dalam bahasa Arab kata maaf terambil dari kata al-' $A f W$, yang berasal dari akar kata yang terdiri dari huruf 'ain, fa' dan wauw. Maknanya berkisar pada dua hal, yaitu meninggalkan sesuatu dan memintanya. Secara bahasa kata 'Afw memiliki dua makna dasar, yakni tarku asy syai (meninggalkan sesuatu) dan Thalabu asy Syai (meminta sesuatu). ${ }^{76}$ Quraish Shihab mendefinisikan 'Afw dengan arti membinasakan serta mencabut akar sesuatu. ${ }^{77}$ Dari sini kemudian

\footnotetext{
${ }^{72}$ Fuad Al-Aris, Tafsir Psikologi, hlm. 532

${ }^{73}$ Baqhawi, Ma'lim Al-Tanzil, Tafsir Surat Yūsuf Ayat: 98, Jilid. 5, hlm. 514

${ }_{74}^{74}$ M. Darwis Hude, Emosi Penjelajahan Religio-Psikologis, hlm. 281

75 Budiono, Kamus Ilmiah Populer Internasional, (Surabaya: Karya Harapan, T.th), hlm. 378

76 Muhammad Syafi'i Antonio, Asma'ul Husna For Success in Business \& Life (Jakarta: Tazkia Publishing, 2009), Cet. 3, hlm. 379

${ }^{77}$ M. Quraish Shihab, Menyingkap Tabir Ilahi (Jakarta: Lentera Hati, 2004), Cet. 3, hlm. 364
} 
lahir ' $A f w$, yang berarti meninggalkan sanksi terhadap yang bersalah (memaafkan).

Pesan yang ketiga adalah dzikrullah, dalam ayat 86 dijelaskan bahwa Dzikrullah dilakukan Nabi Ya'qūb untuk menenangkan keadaannya yang sedang dalam keadaan teramat sangat sedih, karena kehilangan Yūsuf dan Bunyamin, beliau memilih hanya mengadukan kesusahan dan kesedihanya hanya kepada Allah swt. Walaupun secara lafdzi kata dzikir tidak disebutkan dalam ayat ini, namun secara maknawi dzikir (dalam artian mengingat Allah swt) disebutkan dalam ayat ini.

Pada ayat sebelumnya dinyatakan bahwa anak-anak Ya'qūb mengungkapkan kekhawatiran mereka kepada ayahnya secara bertahap. Pertama-tama mereka menyebut kondisi Ya'qūb yang masih mengingat Yūsuf. Bagi mereka, kepedihan Ya'qūb yang berkepanjangan itu sudah tidak logis. Sebab, mereka menganggap Yūsuf sudah tidak ada, berbeda halnya dengan Ya'qūb yang meyakini bahwa ia masih hidup. Kemudian mereka mengungkapkan kondisi fisik Ya'qūb yang semakin lemah. Dan yang terakhir, mereka mengungkapkan dampak lebih berat yang mungkin dirasakan atau menimpa Ya'qūb. Mereka berkata: “Atau (engkau) termasuk orang yang binasa". Tentu saja ungkapan seperti itu tidak disukai Ya'qūb. Tentu saja ia mengetahui, tindakan menyakiti apalagi membunuh diri sendiri adalah tindakan yang diharamkan Allah swt. dan bertentangan dengan akal sehat. Oleh sebab itu Ya'qūb menjawab ungkapan mereka dalam ayat selanjutnya:

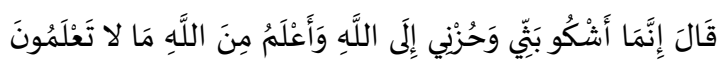

"Ya'qūb menjawab: "Sesungguhnya hanyalah kepada Allah Aku mengadukan kesusahan dan kesedihanku, dan Aku mengetahui dari Allah apa yang kamu tiada mengetahuinya".

Ketika menggambarkan kesedihan yang dideritanya, Ya'kub menggunakan kata "batstsi" yang secara harfiah berarti kerisauan yang sangat besar dan tidak bisa disembunyikan sehingga akhirnya terlihat oleh orang lain. Ya'kub tidak ingin memperlihatkan kesedihan dan dukanya kepada manusia. Ia menjauhkan diri dari orang lain. Ia tidak mau mengadu kepada seorangpun. Ketika orang-orang berada disekitarnya dan ingin 
menghiburnya, Ya'kub mengungkapkan secara terbuka bahwa ia mengadukan kesedihannya kepada Tuhan.

Ungkapan dan tutur kata Ya'qūb dalam ayat di atas memberi kita pelajaran yang berharga. Ia mengajari kita bagaimana menata adab dan prilaku kita dihadapan Allah swt. serta bagaimana seharusnya kita bersikap kepada sesama manusia. Orang yang tinggi tingkatan imannya tidak akan pernah meminta bantuan dan mengadukan permasalahannya kepada selain Allah swt. $^{78}$

Dzikrullah berasal dari kata ذكر bermakna الصفى yaitu bersih dan hening. Wadahnya adalah الوفى artinya menyempurnakan. Dan syaratnya adalah الحضيور artinya hadir sepenuhnya, hamparannya adalah amal saleh. Dalam pengertian ibadah, dzikir adalah mengingat atau menyebut nama Allah swt. ${ }^{79}$ Dalam surat AlAhzab ayat 41, Allah swt. memerintahkan kepada orang-orang beriman untuk berdzikir dengan sebanyak-banyaknya dan dalam surat Al-Imran ayat 191, disebutkan bahwa berdzikir itu bukan hanya diwaktu shalat saja, namun dalam keadaan berdiri, duduk dan berbaring.

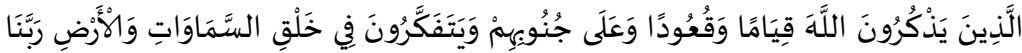

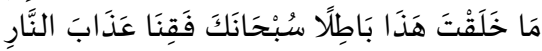

"(yaitu) orang-orang yang mengingat Allah sambil berdiri atau duduk atau dalam keadan berbaring dan mereka memikirkan tentang penciptaan langit dan bumi (seraya berkata): "Ya Tuhan kami, tiadalah Engkau menciptakan Ini dengan sia-sia, Maha Suci Engkau, lindungilah kami dari siksa neraka".

Dari ayat di atas dapat kita pahami bahwa mengingat Allah swt. adalah suatu hal yang mutlak dimanapun, kapanpun dan dalam keadaan apapun. Sebagaimana penafsiran Hamka, beliau mengatakan bahwa mengingat Allah swt. itu tidak terbatas waktu, di darat maupun di laut, dalam keadaan kaya ataupun miskin, dalam keadaan sehat ataupun sakit, dalam keadaan bahagia ataupun sedih. ${ }^{80}$

\footnotetext{
${ }^{78}$ Fuad Al-Aris, Tafsir Psikologi, hlm. 467

${ }^{79}$ M. Zain Abdullah, Dzikir dan Tasawuf, (Surakarta: Qaula, 2007),
} hlm. 82

${ }^{80}$ Hamka, Tafsir al-Azhar, Vol 22, hlm. 53 
Dzikrullah (mengingat Allah swt) merupakan salah satu model pengalihan dari masalah yang dihadapi. Dengan mengingat Allah swt. dalam wujud kalimah thayyibah, wirid, do'a, dan tilawah al-Qur'an hati akan merasa tentram dalam menghadapi masalah, atau ketika harapan tak terpenuhi. ${ }^{81}$ Sebagaimana firman Allah swt. dalam surat Ar-Ra'ad ayat: 28

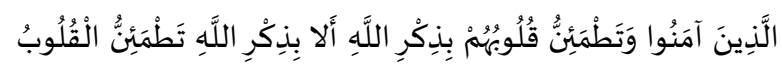

"(yaitu) orang-orang yang beriman dan hati mereka manjadi tenteram dengan mengingat Allah. Ingatlah, Hanya dengan mengingati Allah-lah hati menjadi tenteram".

Dengan mengingat Allah swt. dalam segala situasi, maka sirkuit penghubung antara manusia dengan qalb-nya senantiasa dalam keadaan stand by (posisi on). Tidak ada lagi kesempatan masuk bagi keputus-asaan, prejudice (su' al- zhann), amarah (alghadhab), dan sifat-sifat buruk lainnya. Dengan dzikrullah yang disertai penghayatan, sifat-sifat buruk akan tertahan sebelum bersarang dalam diri manusia. ${ }^{82}$

Emosi positif yang memancar dalam bentuk dzikrullah mampu memblokade emosi-emosi negatif dari diri kaum beriman. Itu sebabnya, dzikrullah dimasukkan dalam kategori pengalihan (displacement) karena berfungsi mengalihkan emosi negatif ke emosi positif. Pemahaman terhadap makna-makna simbolik yang terkandung pada dzikrullah menghembuskan angin ketenangan dan persepsi positif terhadap Allah swt., sehingga mengenyahkan kecenderungan-kecenderungan negatif dalam menyikapi sesuatu. $^{83}$

\section{Kesimpulan}

Setelah melalui pemaparan serta analisa berkenaan dengan ayat-ayat psikologi dalam surat Yūsuf, mengajarkan kepada kita betapa kebaikan akan dibalas dengan kebaikan. Kebaikankebaikan yang terdapat dalam surat Yūsuf diantaranya adalah tidak mencaci maki saat Ya'qūb marah, tidak dendam saat Yūsuf di dzholimi, serta bersabar dan berserah diri saat Ya'qūb ditimpa

\footnotetext{
${ }^{81}$ M. Darwis Hude, Emosi Penjelajahan Religio-Psikologis, hlm. 268

${ }^{82}$ M. Darwis Hude, Emosi Penjelajahan Religio-Psikologis, hlm. 268

${ }^{83}$ M. Darwis Hude, Emosi Penjelajahan Religio-Psikologis, hlm. 270
} 
duka cita karena dibohongi. Ini semua mampu dilakukan oleh Nabi Ya'qūb dan Nabi Yūsuf karena keduanya mampu mengendalikan emosinya. Sehingga dapat disimpulkan bahwa ada dua cara untuk mengendalikan emosi yang terdapat dalam surat Yūsuf. Yang pertama dengan cara Displacement (pengalihan) yaitui Dzikrullah. Yang kedua dengan cara Coping (menerima atau menjalani segala hal yang terjadi dalam kehidupan) yang di dalamnya meliputi sabar dan memaafkan. Dan dalam surat Yūsuf sekurang-kurangnya terdapat tiga manfaat bagi orang-orang yang mampu mengendalikan emosi, yaitu pertama, menghindarkan dari kebencian dan perpecahan yaitu bahwa Nabi Ya'qūb menyakini kalau Nabi Yūsuf tidak dimakan Serigala, dengan ungkapan: "Sebenarnya dirimu sendirilah yang memandang baik perbuatan (yang buruk) itu". Jika salah seorang diatara kita yang mengalami keadaan serupa itu, bisa jadi langkah pertama yang kita lakukan adalah melampiaskan kemarahan dan mencaci maki mereka. ${ }^{84}$ Kedua, mensukseskan rencana bahwa Nabi Yūsuf sebagaimana manusia kebanyakan, meresa marah dan kesal. Setelah beliau mendengar tuduhan yang dilontarkan oleh saudara-saudaranya, bahwa beliau pernah mencuri. Namun Nabi Yūsuf memiliki keistimewaan dibanding dengan manusia lainya, sehingga beliau mampu mengendalikan emosinya dengan menyembunyikan kemarahan dan kejengkelan yang beliau rasakan saat itu. ${ }^{85}$

Dan ketiga membawa kepada kemenangan dan kebahagiaan dengan kisah perjalanan Nabi Yūsuf ini diakhiri dengan berkumpulnya semua anggota keluarganya. Sebagaimana yang pernah Yūsuf katakan pada ayahnya dahulu mengenai mimpinya sewaktu kecil. Yang terdapat pada awal-awal surat ini. Dalam mimpinya itu beliau melihat sebelas bintang, matahari dan bulan yang semuanya bersujud padanya, dan mimpi itu kini benarbenaar menjadi nyata. ${ }^{86}$ Dapat dilihat dalam ayat 99 dan 100 , kedua ayat inilah yang menggambarkan puncak dari suatu kemenangan dan kebahagiaan dari semua rencana yang sejak awal dirancang oleh Yūsuf dengan penuh kecerdasan akal dan emosionalnya. Kebahagiaan yang terlihat dalam ayat ini, salah

\footnotetext{
${ }^{84}$ Fuad Al-Aris, Tafsir Psikologi, hlm. 104

${ }^{85}$ Fuad Al-Aris, Tafsir Psikologi, hlm. 428

${ }^{86}$ Fuad Al-Aris, Tafsir Psikologi, hlm. 516
} 
satunya adalah ekspresi emosi bahagia Nabi Yūsuf saat bertemu kedua orang tuanya, yaitu merangkulnya.

\section{DAFTAR PUSTAKA}

Abu Fida' Isma'il Bin Katsir Al-Quraisyi Ad-Dimasyqi, Tafsir Al-Qur'an Al-Adzim, dari Al-Maktabah Al-Syâmilah, (Bairut: Dar Al-Kutub Al-'Ilmiyah, 1419)

Aliah B. Purwakania Hasan, Psikologi Perkembangan Islam, (Jakarta: Raja Grafindo Persada, 2008)

A.W. Munawwir, Kamus Al-Munawwir, (Surabaya: Pustaka Progresif, 1997)

Baqhawi, Abu Muhamad Al-Husayn Ibn Mas'ûd Al-Farra', Ma'alim Al-Tanzil, dari Al-Maktabah Al-Syâmilah, (Bairut: Dar Ihya At-Tutars Al-'Arabi, 1420)

Budiono, Kamus Ilmiah Populer Internasional, (Surabaya: Karya Harapan, T.th)

Charles C. Mans, Emotional Dicipline, 5 Langkah Menata Emosi Untuk Merasa Lebih Baik Setiap Hari, Trj, Aloysius Rudi Purwanta, (Jakarta: Gramedia Pustaka, 2007)

Daniel Goleman, Kecerdasan Emosional, Terjemah, Hariono S. Imam, (Jakarta: Gramedia Pustaka Utama, 1997)

Departemen Agama RI, Al-Qur'an Dan Tafsir, (Jakarta: Lentera Abadi, 2010)

Depdikbud, Kamus Besar Bahasa Indonesia, (Jakarta: Balai Pustaka, 1990)

Fuad Al-Aris, Tafsir Psikologi Lathaif Al-Tafsir Min Surah Yūsuf, trj, Fauzi Bahrezi, dengan Judul, Pelajaran Hidup Surah Yūsuf, (Jakarta: Zaman, 2013) 
Hasbi Ash-Shidiqy, Ilmu Al-Qur'an Dan Tafsir, (Semarang: Pustaka Rizki Putra, 2009)

Hendra Surya, Jadilah Pribadi Yang Unggul, (Jakarta: Gramedia, 2010)

Ibn Manzhūr, Lisan al-'Arab, (Kairo, Dār al-Ma'ārif, t.th.)

Ibnu Qayyim Al-Jauziyah, Sabar Perisai Seorang Mukmin, Terj, Fadh, (Jakarta: Pustaka Azzam, 2002)

Jalaluddin, Psikologi Agama, (Jakarta: Raja Grafindo Persada, 2011)

Jalaluddin Al-Mahally, Jalaluddin Asy-Syuyuti, Tafsir AlJalalain, dari Al-Maktabah Al-Syâmilah, (Kairo: Dar AlHadits, t.th)

Kuntowijoyo, Islam sebagai Ilmu, Epistemologi, metodologi, dan Etika, (Yogyakarta: Tiara Wacana, 2006)

Mahmud Yunus, Kamus Arab-Indonesia, (Jakarta: Yayasan Penyelenggara Penterjemah atau Penafsiran Al-Qur'an)

Martin Wijokongko, Keajaiban Dan Kekuatan Emosi, (Yokyakarta: Kanisiun, 2011)

Mohamad Ali, Pendidikan Untuk Pembangunan nasional, (Jakarta: Grasindo, 2009)

Muhammad Fu'ad Abd al-Baqi, Al-Mu'jam Al-Mufahras li Alfadhzi Al-Qur'an (Cairo: Dar al-Kutub al-Mishriyah, 1364)

Muhamad Bin Jarir Bin Yazid Bin Katsir Bin Kholib Al-Amli, Abu Ja'far At-Thabari, Jami' Al-Bayan Fi Ta'wil AlQur'an, dari, Al-Maktabah Al-Syâmilah. (Muassasah AlRisalah, 2000)

Muhammad Syafi'i Antonio, Asma'ul Husna For Success in Business \& Life (Jakarta: Tazkia Publishing, 2009)

M. Darwis Hude, Emosi Penjelajahan Religio-psikologis Tentang Emosi Manusia Di dalam Al-Qur'an, (Jakarta: Erlangga, 2006)

M. Nasib ar-Rifaei, Taisîrû al-Aliyyul Al-Qadîr li Ikhtishâri Tafsîr Ibnu Katsir, terj. Syihabuddin, (Jakarta: Gema Insani, 1999) 
Alim Sofiyan

M. Quraish Shihab, Menyingkap Tabir Ilahi (Jakarta: Lentera Hati, 2004)

-------------, Tafsir al-Mishbāh, Pesan, Kesan, dan Keserasian al-Qur'an, (Jakarta: Lentera Hati, 2001)

M. Zain Abdullah, Dzikir dan Tasawuf, (Surakarta: Qaula, 2007)

Hamka, Tafsir al-Azhar, (Jakarta: Panjimas, 1988)

Syihābuddin Mahmūd Ibnu 'Abdullah Al-Husaini Al-Alūsi, Ruhu Al-Ma'ani Fi-Tafsir Al-Qur'an Al-Adzim, dari Maktabah Al-Syâmilah, (Bairut: Dar Al-Kutub Al-Ilmiyah, 1415)

Syeh Muhammad Ghazali, Tafsir Tematik Dalam Al-Qur'an, trj, Qodirun Nur, dan Ahmad Musyafiq, (Jakarta: Gaya Media Pratama, 2005) 